\title{
FATAL BRONCHIAL ASTHMA \\ A SERIES OF FIFTEEN CASES WITH A REVIEW OF THE LITERATURE \\ BY
}

\author{
B. V. EARLE
}

From the Westminster Hospital, London

(RECEIVED FOR PUbliCATION DECEMber 8, 1952)

The chief object of this study is to investigate the cause and incidence of death from asthma. The records of 15 cases of fatal asthma have been collected. Three were observed personally at the Westminster Hospital and at the Willesden General Hospital, London, and the others obtained from the case records of these hospitals and of Llandough Hospital, Cardiff, the Cardiff Royal Infirmary, the Hospital for Sick Children, London, and Graylingwell Hospital, Chichester.

There is a widespread impression that death never results from uncomplicated bronchial asthma, and this view is supported by the older authorities. Trousseau described it as "le brevet de longue vie." Osler quotes Oliver Wendell Holmes as calling asthma "the slightest ailment that promotes longevity." Modern textbooks make little reference to death ensuing from this condition, and in this country only one case with post-mortem findings has been recorded (Thomson, 1945). It is now becoming recognized that asthma may be fatal, but death in hospital remains rare because most cases are treated at home by their own doctors.

\section{Literature of Fatal CASES}

Tables I, II, and III contain a summary of 160 cases so far reported in the world literature. Cases without adequate post-mortem studies and clinical histories have not been included, but otherwise the list is as complete as possible.

The pathological findings in most cases were as follows: (1) Gross emphysema; (2) the bronchial tree plugged with sticky mucus; (3) the bronchial walls thickened by muscular hypertrophy, widening of the basement membrane, and oedema of all layers; (4) infiltration of the bronchial walls by eosinophils; (5) hyperactivity of the bronchial mucous glands. The above features are listed as " usual" in the Tables.

The cases have been classified under three headings: (1) Uncomplicated fatal asthma, (2) asthma the chief cause of death, (3) death from other causes. There were altogether 90 cases in which asthma had been the only or chief cause of death. Forty-one of these were male and 49 female. More than half of the deaths took place between the

TABLE I

NECROPSY REPORTS IN CASES OF ASTHMA RECORDED IN THE WORLD LITERATURE

\begin{tabular}{|c|c|c|c|c|c|}
\hline Year & Author & $\begin{array}{c}\text { Total } \\
\text { No. } \\
\text { of } \\
\text { Cases }\end{array}$ & $\begin{array}{l}\text { Uncom- } \\
\text { plicated } \\
\text { Fatal } \\
\text { Asthma }\end{array}$ & $\begin{array}{c}\text { Asthma } \\
\text { the Chief } \\
\text { Cause of } \\
\text { Death }\end{array}$ & $\begin{array}{l}\text { Death } \\
\text { from } \\
\text { Other } \\
\text { Causes }\end{array}$ \\
\hline $\begin{array}{l}1922 \\
1923\end{array}$ & \multirow{19}{*}{ 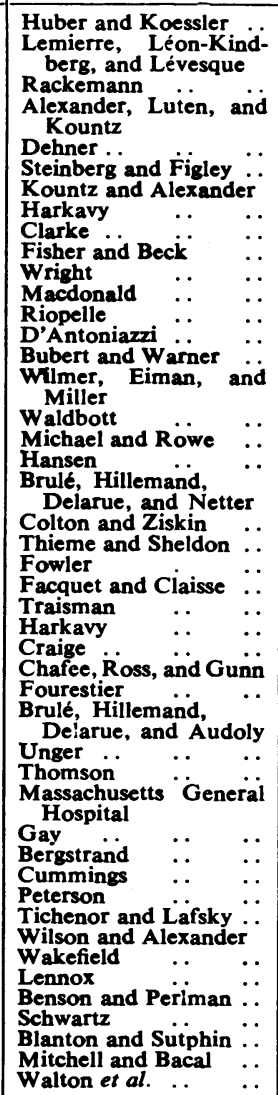 } & \multirow{2}{*}{$\begin{array}{r}21 \\
1 \\
1 \\
1\end{array}$} & \multirow[t]{2}{*}{$\begin{array}{l}5 \\
1\end{array}$} & & \multirow[t]{2}{*}{13} \\
\hline $\begin{array}{l}1926 \\
1927\end{array}$ & & & & & \\
\hline $\begin{array}{l}1927 \\
1928 \\
1928\end{array}$ & & \multirow{6}{*}{$\begin{array}{l}1 \\
2 \\
3 \\
2 \\
1 \\
1 \\
1 \\
8 \\
1 \\
1 \\
1 \\
1\end{array}$} & 2 & \multirow[t]{4}{*}{1} & 1 \\
\hline $\begin{array}{l}1928 \\
1930\end{array}$ & & & 2 & & \multirow[t]{2}{*}{1} \\
\hline $\begin{array}{l}1930 \\
1930\end{array}$ & & & 1 & & \\
\hline 1930 & & & 1 & & 1 \\
\hline $\begin{array}{l}1933 \\
1933\end{array}$ & & & $\begin{array}{l}1 \\
1\end{array}$ & \multirow[t]{2}{*}{2} & \multirow[t]{2}{*}{5} \\
\hline $\begin{array}{l}1933 \\
1935 \\
1936\end{array}$ & & & i & & \\
\hline $\begin{array}{l}1935 \\
1935 \\
1936 \\
1935\end{array}$ & & $\begin{array}{l}2 \\
2 \\
1 \\
1\end{array}$ & $\begin{array}{l}2 \\
2 \\
1 \\
1\end{array}$ & & 1 \\
\hline \multirow{4}{*}{$\begin{array}{l}1936 \\
1938 \\
1937 \\
1939 \\
1941 \\
1941 \\
1941 \\
1942 \\
1943 \\
1943\end{array}$} & & \multirow{4}{*}{$\begin{array}{r}6 \\
17 \\
2 \\
1 \\
1 \\
4 \\
7 \\
6 \\
1\end{array}$} & \multirow{2}{*}{$\begin{array}{l}3 \\
2 \\
1 \\
1 \\
1\end{array}$} & & $\begin{array}{r}2 \\
10 \\
1\end{array}$ \\
\hline & & & & & 4 \\
\hline & & & 5 & $\begin{array}{l}\mathbf{2} \\
\mathbf{3}\end{array}$ & \multirow[t]{2}{*}{3} \\
\hline & & & 1 & 1 & \\
\hline $\begin{array}{l}1945 \\
1945 \\
1946\end{array}$ & & $\begin{array}{l}5 \\
1 \\
1\end{array}$ & $\begin{array}{l}3 \\
1\end{array}$ & 2 & 1 \\
\hline \multirow{6}{*}{$\begin{array}{l}1946 \\
1946 \\
1946 \\
1947 \\
1947 \\
1947 \\
1947 \\
1948 \\
1948 \\
1949 \\
1949 \\
1950 \\
1951\end{array}$} & & \multirow{5}{*}{$\begin{array}{r}24 \\
4 \\
1 \\
1 \\
1 \\
1 \\
1 \\
1 \\
3 \\
1 \\
1 \\
1 \\
13\end{array}$} & \multirow[t]{2}{*}{$\begin{array}{l}2 \\
1\end{array}$} & 4 & $\begin{array}{r}18 \\
4\end{array}$ \\
\hline & & & & 1 & \multirow[t]{3}{*}{1} \\
\hline & & & \multirow[t]{2}{*}{1} & $\begin{array}{l}1 \\
1\end{array}$ & \\
\hline & & & & 2 & \\
\hline & & & & $\frac{1}{2}$ & 1 \\
\hline & Total .. & 160 & $56(35 \%)$ & $34(21 \%)$ & $\overline{70(44 \%)}$ \\
\hline
\end{tabular}


TABLE II

SUMMARY OF 56 DEATHS DUE TO UNCOMPLICATED ASTHMA RECORDED IN THE LITERATURE

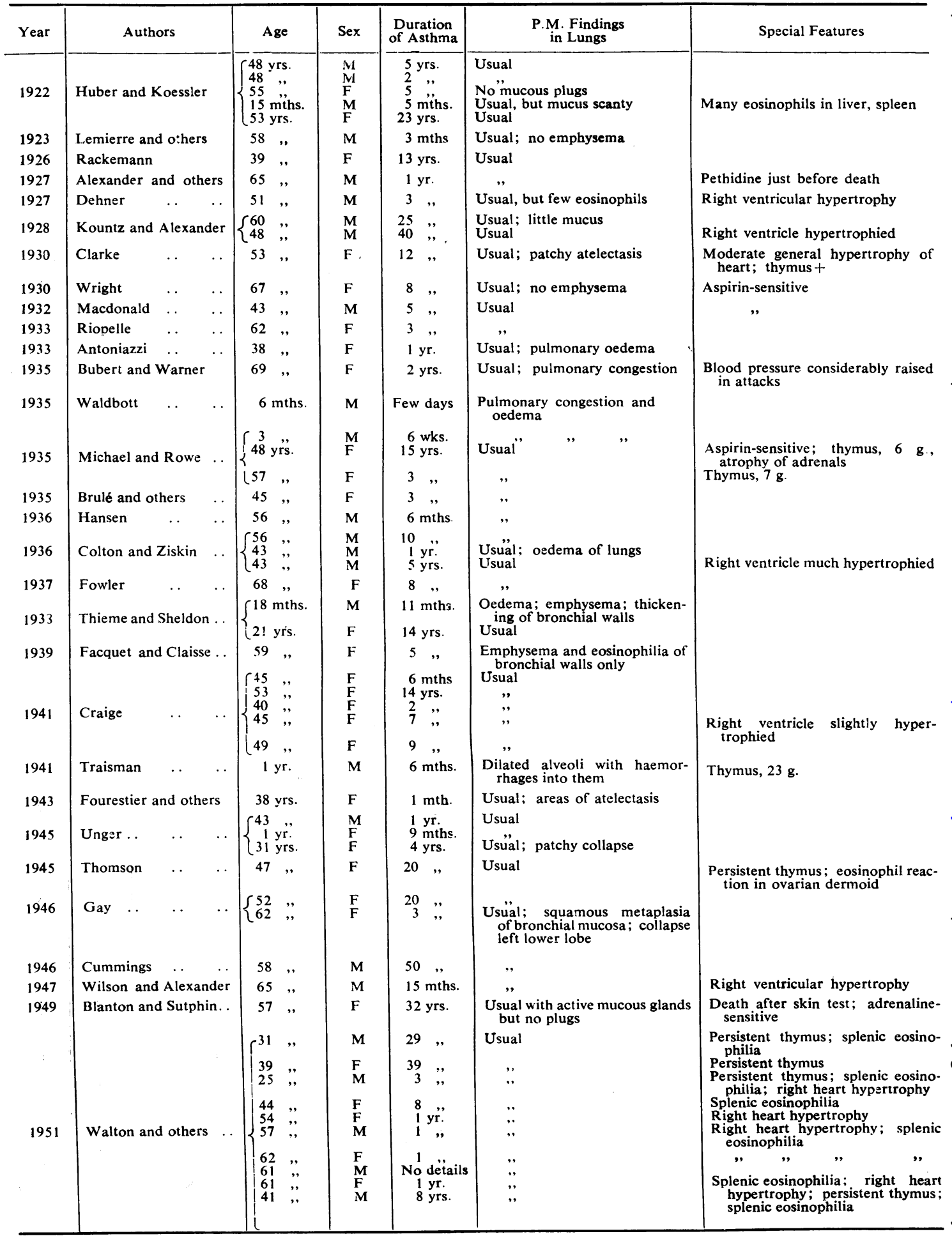


TABLE III

SUMMARY OF 34 CASES OF ASTHMA AS CHIEF CAUSE OF DEATH RECORDED IN THE LITERATURE

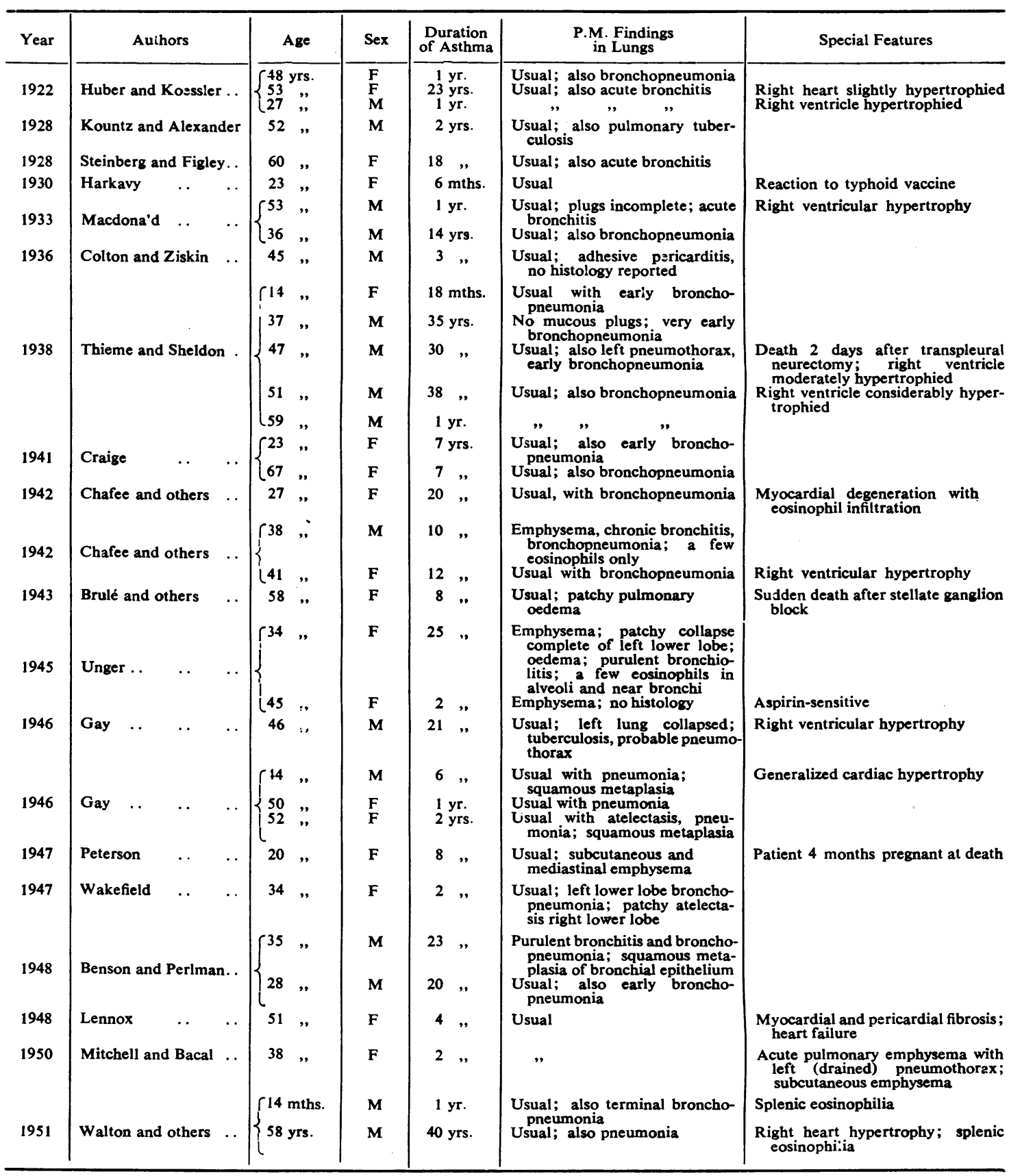


ages of 40 and 60 years. There were seven deaths before the age of 5 , but only eight deaths between 5 and 30 years. Forty-nine patients had died within five years and 62 within 10 years of the onset of asthma.

The chief complication was found to be bronchopneumonia (20 cases). Inflammatory changes had not usually been enough to obliterate the underlying pathological picture of asthma. Mediastinal emphysema with pneumothorax was seen in four cases. A persistent or overweight thymus was noted nine times. Right ventricular hypertrophy of moderate to considerable degree was found in

TABLE IV

SUMMARY OF SEVEN CASES WITH DEATH DUE TO UNCOMPLICATED ASTHMA IN PRESENT SERIES

\begin{tabular}{|c|c|c|c|c|c|}
\hline $\begin{array}{c}\text { Case } \\
\text { No. }\end{array}$ & Age & Sex & $\begin{array}{c}\text { Duration } \\
\text { of } \\
\text { Asthma }\end{array}$ & $\begin{array}{l}\text { P.M. } \\
\text { Findings } \\
\text { in Lungs }\end{array}$ & $\begin{array}{l}\text { Special } \\
\text { Features }\end{array}$ \\
\hline $\begin{array}{l}1 \\
2\end{array}$ & $\begin{array}{c}43 \text { yrs. } \\
48 \text { ". }\end{array}$ & $\mathbf{F}$ & $\begin{array}{l}23 \text { yrs. } \\
40 \text { " }\end{array}$ & $\begin{array}{l}\text { Usual } \\
\text { Usual, but no } \\
\text { eos in ophilia; } \\
\text { some oedema of }\end{array}$ & Thymus $23 \mathrm{~g}$. \\
\hline 3 & 30 & $\mathbf{F}$ & $25 "$ & $\begin{array}{l}\text { Usual; some oed- } \\
\text { ema and atelec- } \\
\text { tasis }\end{array}$ & \\
\hline 4 & 6 mths. & $\mathbf{M}$ & 3 mths. & Usual & Patent ductus; \\
\hline 5 & 42 yrs. & $\mathbf{F}$ & 41 yrs. & ", & $\begin{array}{l}\text { Slight hyper- } \\
\text { trophy of } \\
\text { right ven- } \\
\text { tricle }\end{array}$ \\
\hline 6 & 62, & $\mathbf{F}$ & 53 ", & Peribronchial & \\
\hline 7 & 55, & $\mathbf{M}$ & $1 \mathrm{yr}$. & Usual & \\
\hline
\end{tabular}

TABLE V

SUMMARY OF EIGHT CASES WITH ASTHMA AS THE CHIEF CAUSE OF DEATH

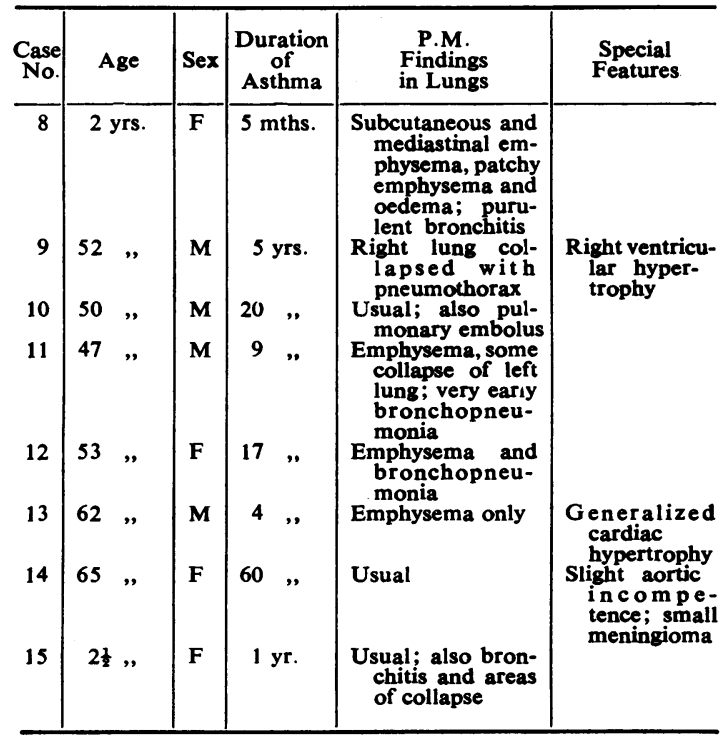

nine of the uncomplicated and five of the complicated cases. Eosinophilia was found in the spleen in 10 cases, in the heart in one, and in the liver and an ovarian dermoid in one.

\section{Present Series of fatal Cases}

Tables IV and V contain an analysis of the main features of fatal cases (15 in all). Case histories are given at the end of this paper (those personally observed in greater detail).

There were nine female and six male patients. Ten died between the ages of 35 and 60 years. Four deaths took place before the age of 5 . There was only one death between the ages of 5 and 35 years. Eight patients out of 15 were dead within ten years of the onset of asthma.

Pathological findings approximate to those found in previously reported cases. Nine of the 15 cases showed the basic changes of asthma already described. Four had emphysema only. Two were complicated by bronchitis, one by early bronchopneumonia, and one by a pulmonary embolus. Considerable enlargement of the right ventricle was seen in one, slight enlargement in another, while a third had hypertrophy of both ventricles. Pneumothorax and mediastinal emphysema were each found once.

\section{The Cause of Death in Asthma}

Mechanism of DeATH.-Most writers are agreed that the chief cause of death is asphyxia due to bronchial obstruction, but not all are agreed as to the cause of the obstruction. The two principal theories are spasm of the bronchial musculature and swelling of the mucous membrane with increased bronchial secretion and the formation of mucous plugs. Most authors attach much more importance to bronchial secretion than to bronchospasm.

THE Role of DRUGS.-Morphine is generally incriminated as a precipitating cause of death. Clarke (1930), Thieme and Sheldon (1938), Craige (1941), Thomson (1945), Unger (1945), and Serafini (1950) all describe patients dying within a few hours of having morphine. Facquet and Claisse's patients (1939) died a few minutes after having been given the drug. Morphine was of great importance in Case 3 of the present series. The patient became semi-comatose soon after $\frac{1}{2}$ grain (30 mg.) had been given. In Case 1 also morphine was a contributory factor.

Aspirin appears to initiate the attack in the small group of asthmatics which is sensitive to the drug. Coke and Coke (1939), Wright (1930), Macdonald (1933), Michael and Rowe (1935), and Unger (1945) all describe deaths in cases sensitive 
TABLE VI

RESPONSE TO DRUGS AND CAUSE OF DEATH IN CASES OF PRESENT SERIES

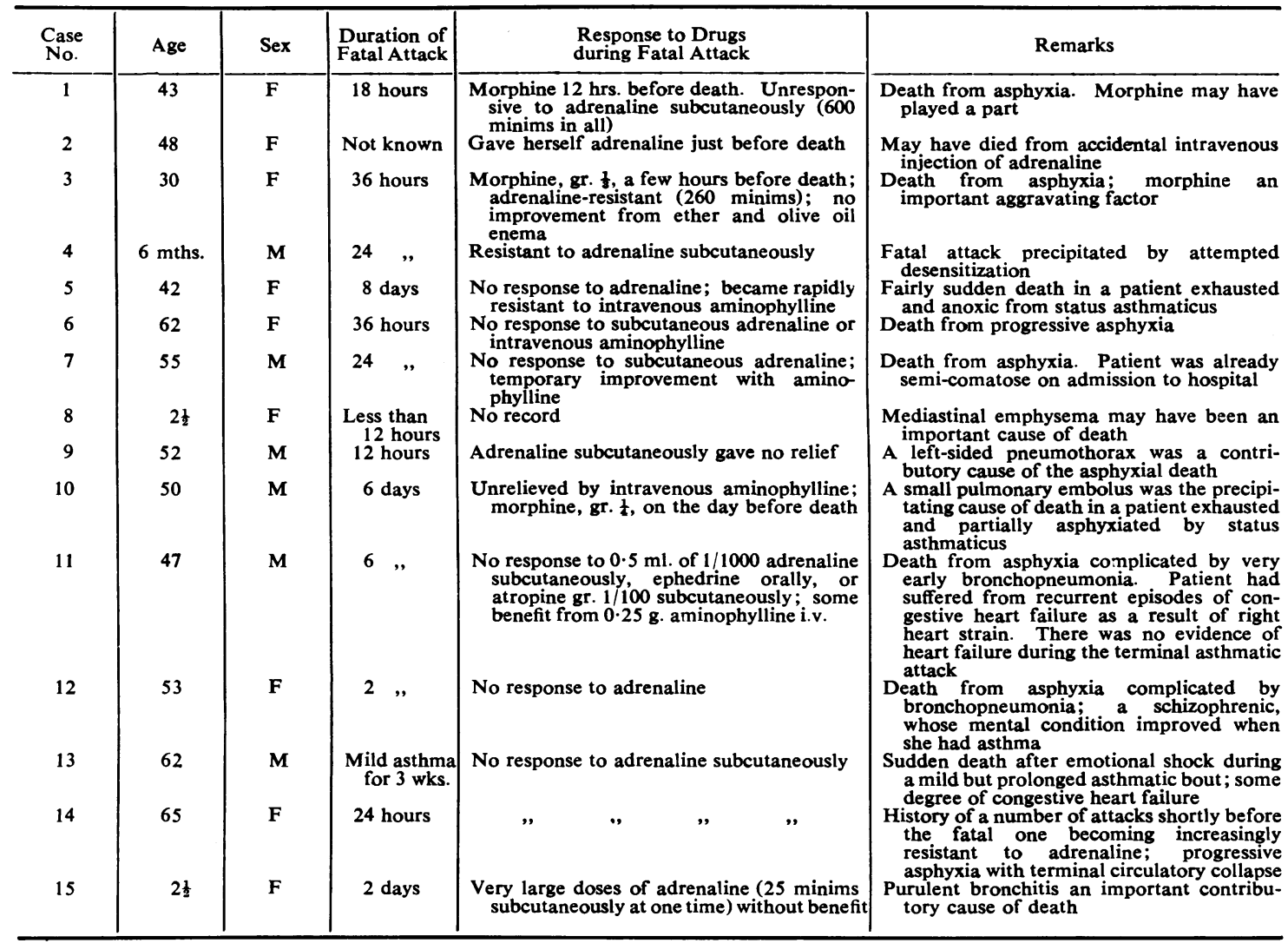

to aspirin. In the case described by Wright there was a violent fatal paroxysm of asthma a few minutes after taking a tablet.

Adrenaline may be dangerous. Very rarely it may produce a generalized reaction with urticaria. This appeared to be fatal in one case (Frankland, personal communication). Over-dosage may be a cause of death, especially in children. Thus Traisman (1941) describes a child of 1 year dying after being given $10 \mathrm{~min}$. ( $0.6 \mathrm{ml}$.) of 1 in 1,000 adrenaline, and Blanton and Sutphin (1949) report sudden death in an asthmatic after $1 \mathrm{ml}$. of 1 in 1,000 adrenaline. Case 2 of the present series died after an injection of adrenaline, probably given intravenously. In cases of heart disease adrenaline is naturally dangerous, while in some people with normal hearts it seems to cause an excessive rise of blood pressure. Gay (1946) describes a patient developing coma and left hemiparesis after $5 \mathrm{ml}$. of 1 in 1,000 adrenaline. Benson and Perlman (1948) believe that adrenaline inhalers are very dangerous because they damage the epithelium of the respiratory tract allowing easy access of pyogenic organisms. They noted 48 deaths in 649 patients using sprays $(7.4 \%)$. In 1,588 patients who did not use them there were 72 deaths (4.5\%). Facquet and Claisse (1939) and Hamburger, Milliez, and Halpern (1947) believe that repeated use of adrenaline may result in increased bronchial secretion of mucus and cause adrenaline " resistance" during an attack. Moulis (1950) noted three deaths in patients who had been taking large amounts of adrenaline.

Villanova (1948) describes fatal cases after intravenous procaine. Intravenous tetraethylammonium bromide has only recently been used for treating asthma, but has already given rise to one death and a number of non-fatal reactions (Schwartz, 1949). According to Vaughan (1948) digitalis may be dangerous in asthma, but he does not offer evidence to support this statement, nor is it substantiated by others. 
Uncomplicated

fatal asthma.
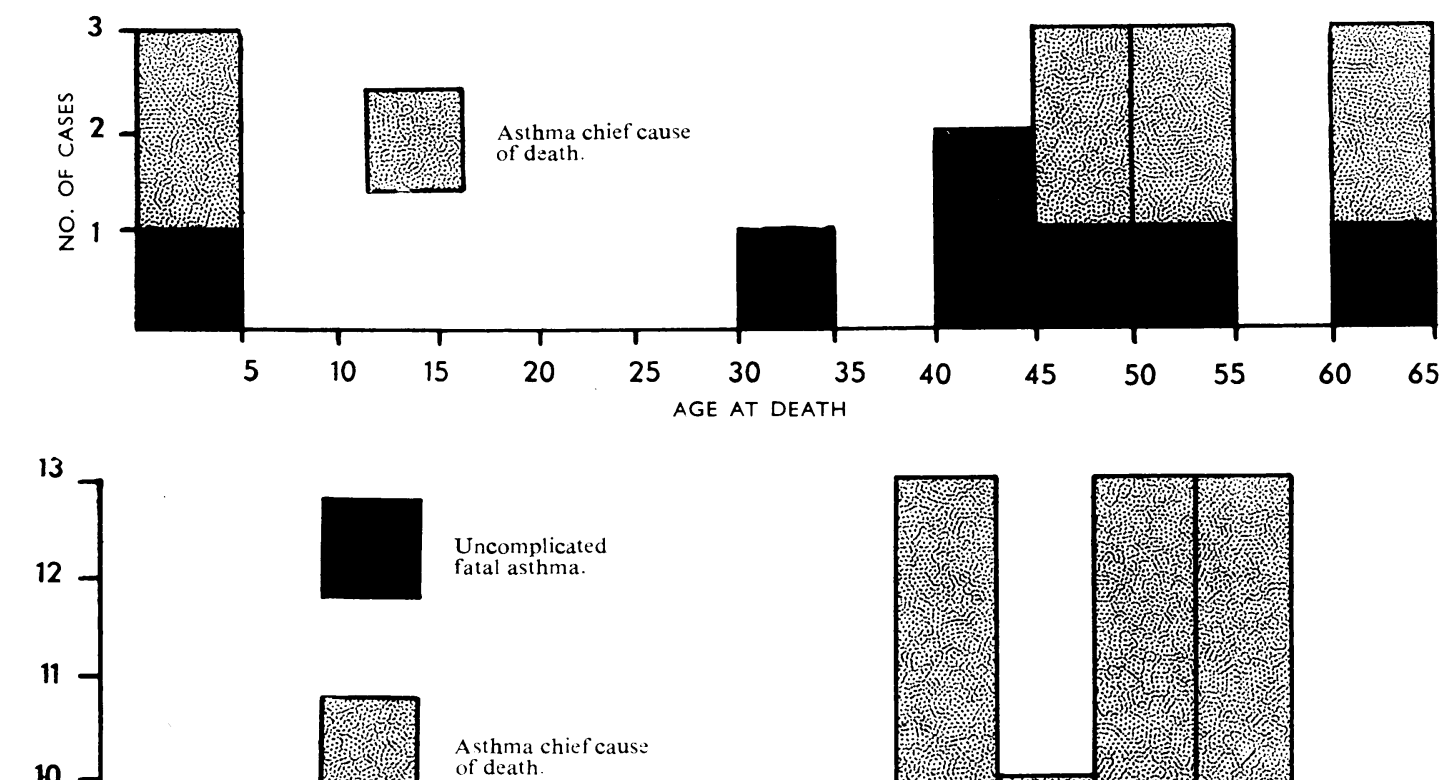

of death

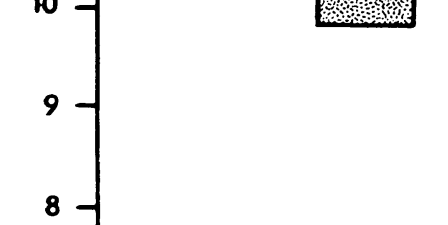

U
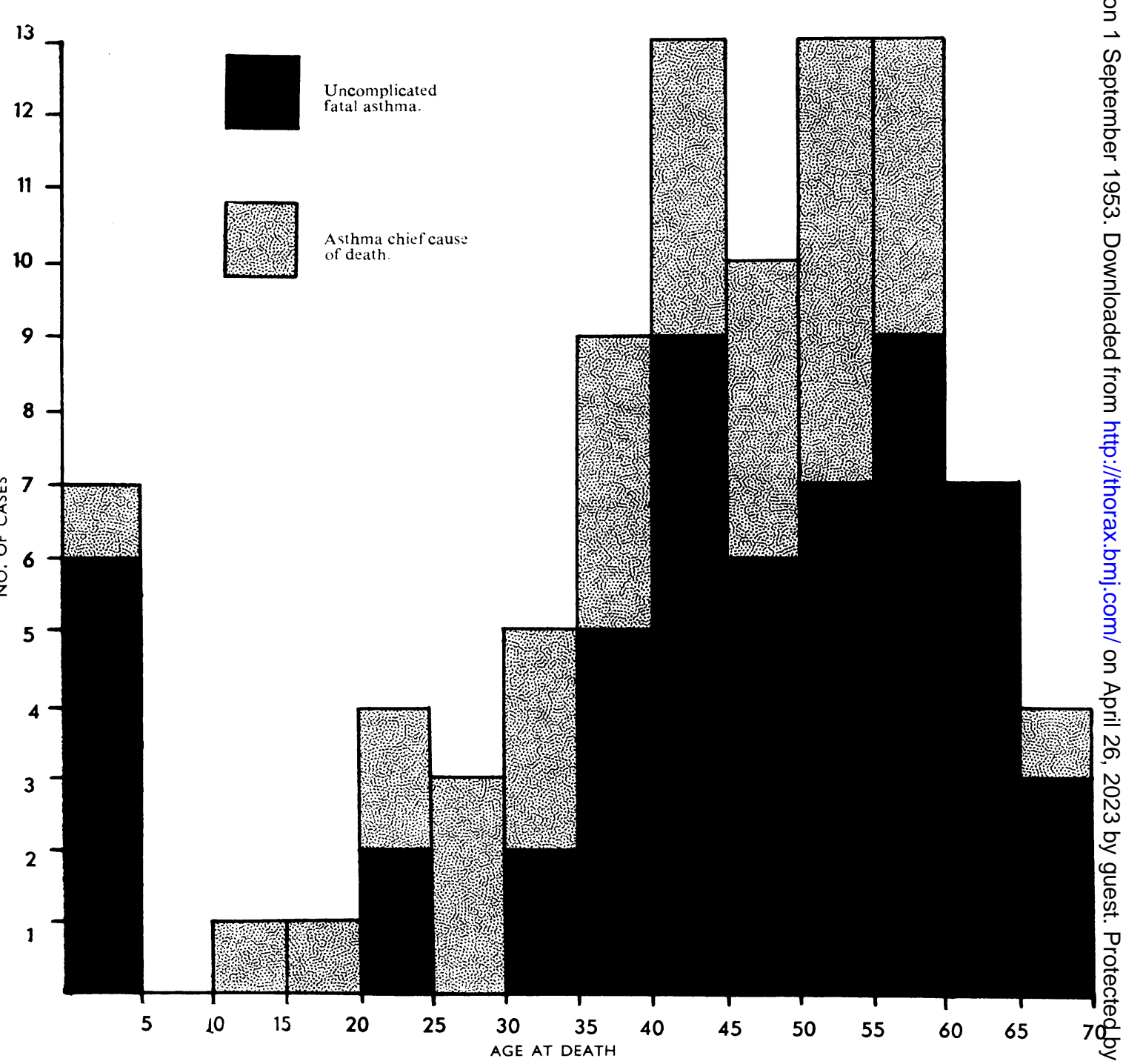

FIG. 1.-Age at death in fatal cases of asthma.

Above, 15 cases of present series. Below, 90 cases recorded in the literature. 
Pethidine is blamed by Wilson and Alexander (1947) and by Walton, Penner, and Wilt (1951) for altogether four deaths.

Anaphylactic Shock and Fatal Asthma.The changes found in the lungs of asthmatics and others who have died from anaphylactic shock may resemble very closely those found in uncomplicated fatal asthma (Meakins, 1944; Vance and Strassmann, 1942; Huber and Koessler, 1922).

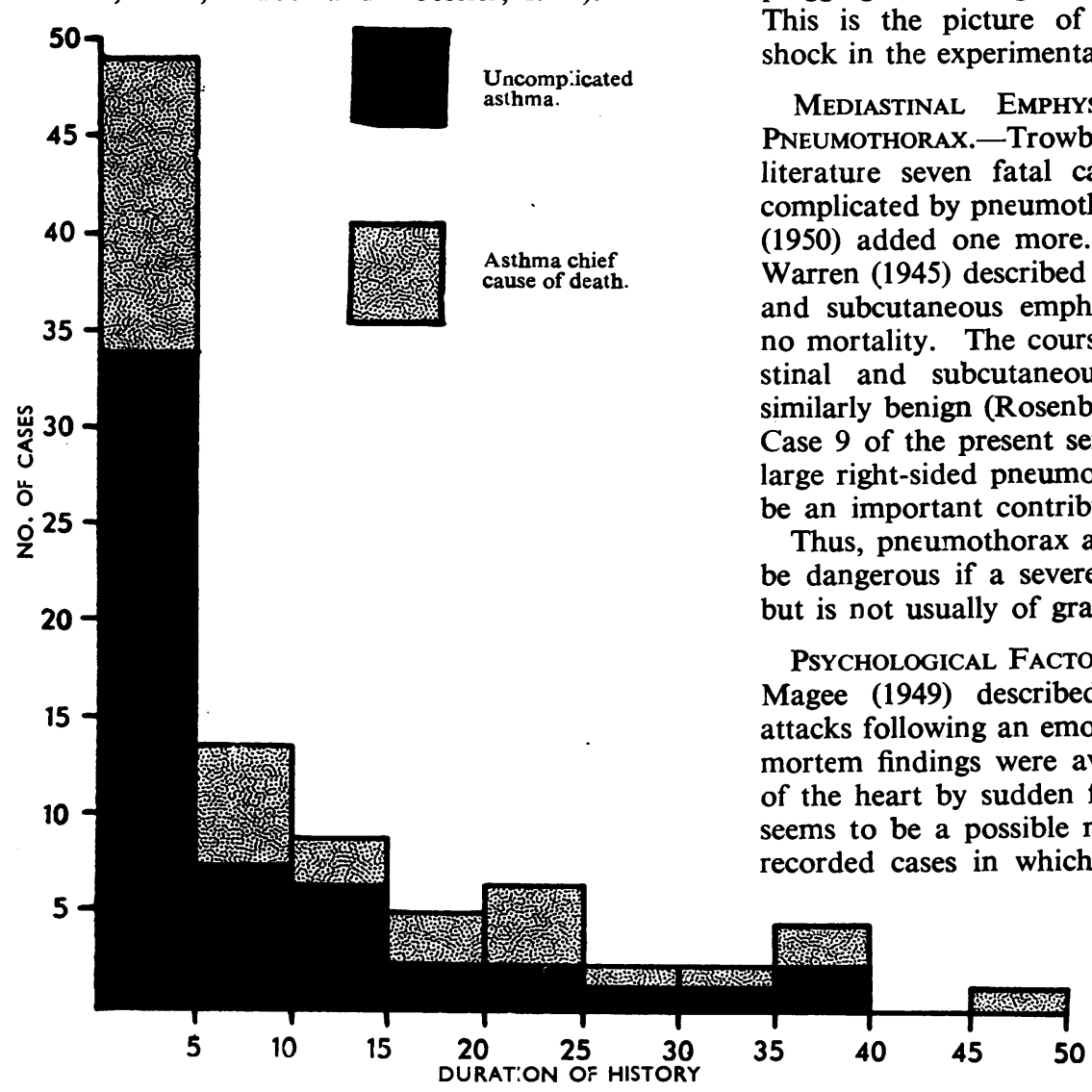

FIG. 2.-Duration of history of asthma at death. Cases recorded in the literature.

or a prolonged attack of asthma. The dangers are discussed by Blanton and Sutphin (1949). Case 4 of the present series was an example of this.

Waldbott (1935) believes that all asthmatic deaths in infancy arise from a kind of anaphylactic shock, i.e., a different process from the mechanism in adults. This concept is supported by the frequent finding of pulmonary oedema without mucous plugging in the lungs of infants dying from asthma. This is the picture of death from anaphylactic shock in the experimental rabbit.

Mediastinal Emphysema aNd SpOntaneous PNEUMOTHORAX.- Trowbridge (1944) found in the feven fatal cases of bronchial asthma Mitchell and Bacal (1950) added one more. Schwartz, Mcllroy, and (1945) described 25 cases of pneumothorax emphysema in asthmatics with thorax which appeared to an important contributory cause of death.

Thus, pneumothorax accompanying asthma may be dangerous if a severe asthmatic attack occurs, seems to be a possible mechanism in some of the rapidly during a slight or moderate attack. Kayssi (1948) showed that stimulation of the vagus nerve may produce sudden death in experimental animals; this may be the mechanism in man

Anaphylactic shock is usually rapidly fatal within minutes to an hour or so, and although associated with bronchospasm is a generalizcd reaction. There is usually peripheral circulatory failure and sometimes convulsions or other evidence of its widespread nature. This is quite a different picture from the gradual suffocation of status asthmaticus. Asthmatics are abnormally liable to horse serum reactions. They may sometimes get over the initial shock only to pass into status asthmaticus. Skin testing in an asthmatic may provoke either a rapidly fatal anaphylactic shock when death has followed very slight trauma to certain regions (e.g., larynx, abdomen). In rare instances the vagal overactivity accompanying asthma perhaps produces the same result.

The Heart and Fatal Asthma.-Cardiac failure is rarely a primary cause of death in uncomplicated asthma. Indeed in a number of fatal cases the heart has continued to beat for a minute or so after respiration has ceased (Thieme and Sheldon, 1938; Bubert and Warner, 1935). In the opinion of most authors significant right ventricular hypertrophy or congestive heart failure are relatively 
uncommon findings in uncomplicated asthma (Kountz and Alexander, 1928; Michael and Rowe, 1935; Vaughan, 1948; Villanova, 1948). Gay (1946) found congestive heart failure in only two of 24 asthmatics dying from various causes. Parkinson and Hoyle in 1937, describing the condition of the heart in 80 cases of emphysema, did not find it more frequently affected in those cases complicated by asthma.

Three cases of the present series had evidence of right heart strain as shown by right ventricular hypertrophy at necropsy. Only in Case 13 was there any degree of congestive failure at death. Case 11 suffered several bouts of heart failure, but when he died during an attack of asthma the heart appeared normal. At necropsy the heart was found to be of normal size with a healthy myocardium. During episodes of failure the electrocardiogram had shown right ventricular preponderance, afterwards returning to normal.

Thus the weight of evidence is against heart failure as an important cause of death in asthma. But in some long-standing cases with much emphysema it may be so.

The Role of Pulmonary Infections.-In many fatal cases of status asthmaticus very early bronchopneumonic changes are found after death. Often there has been little or no fever and no clinical evidence of bronchopneumonia, the course of the disease having been identical with uncomplicated fatal asthma. In most instances it seems reasonable to assume that the inflammatory changes were incidental and that death resulted from asphyxia. In infancy and old age, however, the part played by infection is difficult to assess, since in these age groups a relatively slight infection may be fatal. It is uncertain why these early bronchopneumonic changes should be found. The cases do not present the clinical or pathological picture of terminal bronchopneumonia. In a severe prolonged attack of asthma the patient is often exhausted and unable to take nourishment, but he is not as ill as the patient with malignant disease, uraemia, or similar conditions in whom bronchopneumonia is a common terminal event. In such cases the pneumonia is usually confluent, quite unlike the minimal pneumonic changes found in fatal asthma. It has been suggested that infection arises in the minute atelectatic patches produced by mucous plugs in the smaller bronchioles (Huber and Koessler, 1922; Clarke, 1930). In elderly people the infection may progress and finally dominate the picture, but this does not generally happen.

The part attributed to adrenaline inhalers in reducing the resistance of the bronchial walls to infection has already been referred to. Further work is needed to ascertain how far this is true.

Cases 8, 11, 12, and 15 of the present series showed evidence of bronchitis or very early bronchopneumonic change, but in all the clinical picture was one of status asthmaticus.

\section{Prognosis}

Little information can be gathered from the literature about the prognosis of asthma. Old (1933) analysed life insurance statistics in the U.S.A. and found that among 274 asthmatics the ratio of expected to actual deaths was 100 to 121 ; the death rate from heart disease was three and a quarter times the normal of the population. Dublin and Marks (1933), quoted by Lamson and Butt (1937), found the death rate to be $27 \%$ above normal in a series of mixed patients in the U.S.A. They also found a high rate of heart disease. Diagnoses are not always accurate in life insurance statistics, and the unusually high incidence of heart disease may reflect confusion between cardiac and bronchial asthma. Williams and Williams (1949) followed up 64 cases of asthma over seven to 12 years in England and found that $19.4 \%$ had recovered and $17.2 \%$ had died. Unfortunately, as they point out, their series is too small to warrant statistical analysis. There is no conclusive statistical information available, but the papers quoted suggest that the death rate is higher among asthmatics than among the population as a whole. Most deaths from uncomplicated asthma occur between the ages of 40 and 65 years. A small percentage take place in infancy. Death in a young adult is very rare. Nearly half the total number of fatal cases of asthma have had the disease for less than five years. There is an equal mortality in males and females.

\section{SUMMARY}

Death from uncomplicated bronchial asthma is not as rare as was once supposed. Fatal cases are rare in hospital because status asthmaticus is usually treated at home. A series of 15 fatal cases has been collected and 160 fatal cases published in the world literature have been reviewed.

Death usually results from asphyxia, produced by excessive mucous secretion blocking the air passages. Bronchospasm plays a minor role. Morphine is dangerous because it depresses the respiratory centre and cough reflex so that it hinders expectoration of mucus. Aspirin may provoke violent, even fatal, attacks in asthmatics who are sensitive to it. Adrenaline may be fatal if accidentally or deliberately injected intravenously. Some asthmatics die suddenly without sufficient 
cause being demonstrated at necropsy; vagal inhibition of the heart by physical or psychological stimuli is a possible mechanism.

Heart failure has little importance as an immediate cause of death in asthma. Failure of the right heart takes place only as a result of the emphysema which complicates long-standing asthma. One patient (No. 11) in the reported series developed congestive heart failure secondarily to emphysema and recurrent bronchopneumonia. The heart returned to normal when the pneumonia cleared up. The patient died a year later in status asthmaticus; but even during this fatal attack the heart remained normal, and at necropsy there was no hypertrophy of the right ventricle.

Pulmonary infection is a common complication which tends to prolong the asthmatic attack and may be difficult to diagnose. Resistance to infection may be lowered by the prolonged use of adrenaline inhalers.

On the whole prognosis is good during an attack of status asthmaticus. Death in a young adult is very rare. There is a slight but definite risk to life in the patient aged between 40 and 65 years.

\section{CASE ReCORDS}

Case 1: Fatal Uncomplicated Asthma (from the records of Llandough Hospital). - A woman aged 43 had suffered from asthma since pneumonia at the age of 20. She developed a severe attack which did not respond to adrenaline or morphine $\frac{1}{4}$ grain $(15 \mathrm{mg}$.) and was admitted to hospital the same day. There she was given 1 in 1,000 adrenaline at five to 10 minute intervals in doses of 35 minims $(2 \mathrm{ml}$.), to a total of 600 minims (35 ml.). This produced no relief and she died early next morning. At necropsy both lungs were found to be very emphysematous and moderately congested, with oedema at the bases; there were tenacious mucous plugs in the bronchi and extensive pleural adhesions on the left. Microscopically there was emphysema with oedema and congestion of the alveolar walls, and the bronchi showed disintegration of the mucous membrane, hypertrophy of the muscle layer, and prominent elastic lamina. The right heart was dilated and the abdominal viscera congested. Other findings were normal.

Case 2: Fatal Uncomplicated Asthma (from the records of the Cardiff Royal Infirmary). - A woman aged 48 had suffered from asthma since childhood. At just before midnight she called another occupant of her house and said, "I am dying," then rapidly became unconscious and was dead before the doctor arrived. A hypodermic syringe containing adrenaline was found beside her. At necropsy needle punctures were found on the outer surfaces of both thighs. The trachea and large bronchi were filled with sticky mucus and there were small petechiae at the lower end of the trachea. Both lungs were very emphysematous; the bronchi had thickened walls and contained thick mucous plugs.
The left lung had several small, well-encapsulated caseous areas in the subpleural part of the upper lobe and old adhesions over the greater part of this area. Microscopically there was some lung oedema, the bronchial walls were thickened with prominent muscles, and section through the caseous area showed tuberculosis. There was a persistent thymus, weighing $23 \mathrm{~g}$. Other organs were normal.

Case 3: Fatal Uncomplicated Asthma (from the records of Llandough Hospital). - This 30-year-old woman had had asthma since childhood. She was admitted to hospital in an attack which had started the previous day. Shortly before admission she had been given morphine $\frac{1}{3}$ grain $(20 \mathrm{mg}$.) subcutaneously. She was semiconscious, very dyspnoeic and cyanosed, with very active accessory muscles of respiration and loud expiratory rhonchi. The pulse rate was 135 per minute, regular, of poor volume. Over two and a half hours she was given a total of 440 minims $(26 \mathrm{ml}$.) of 1 in 1,000 adrenaline in divided doses and then an enema of $1 \mathrm{oz}$. $(30 \mathrm{ml}$.) each of ether and olive oil, but she died three hours after admission. At necropsy the lungs showed large areas of atelectasis with surrounding emphysema, bronchioles plugged with thick, tenacious mucus, and hypertrophied small bronchi and bronchioles. The alveolar walls were thickened with eosinophilic material and some alveoli contained eosinophilic strands. Other organs showed no significant change.

Case 4: Fatal Uncomplicated Asthma (from the records of the Hospital for Sick Children, London).This baby was well till the age of 3 months when he developed asthma and eczema. He was breast-fed till 4 months of age when cow's milk precipitated a severe attack. At six months desensitization with a solution derived from milk protein was begun; the third injection was followed after an hour by a severe asthmatic attack. On admission to hospital next day he was moribund and cyanosed. There was very poor air entry, extreme rib recession, and high-pitched expiratory rhonchi. He was given 2 minims $(0.12 \mathrm{ml}$.) of 1 in 1,000 adrenaline, but died an hour later. At necropsy the lungs showed some emphysema, small areas of collapse throughout, and a bronchial tree filled with thick, greenish-yellow mucus. Microscopically the trachea showed some desquamation of the epithelium, active mucous glands, and its wall infiltrated with eosinophils, plasma cells, and lymphocytes. The mucus filling the bronchi and larger bronchioles contained numerous eosinophils, neutrophils, and lymphocytes, and the same cells infiltrated the walls. The smaller bronchioles showed emphysema, collapse, oedema, and wide dilatation. There was histiocytic infiltration of the alveoli, and increased lymphocytes and polymorphs in the pulmonary septa. Other organs showed no significant change.

Case 5: Fatal Uncomplicated Asthma (from the records of Llandough Hospital).-This 42-year-old woman had had asthma since she was a year old. Nine days before admission she developed pneumonia which responded to a sulphonamide, but was followed by asthmatic paroxysms unrelieved by adrenaline. On 
admission she was pale and anxious; respirations were 30 per minute, chest expansion was poor with generalized rhonchi and a loud expiratory wheeze. She did not respond to aminophylline intravenously, or later to the same drug rectally, and died a week after admission after being in status asthmaticus for a week and remaining apyrexial throughout. At necropsy the lungs showed thickened bronchi with tenacious plugs of mucus and no evidence of infection; the heart was normal except for slight hypertrophy of the right ventricle; the only other abnormality found was a uterine fibroid.

Case 6: Fatal Uncomplicated Asthma (from the records of Llandough Hospital). - This 62-year-old woman had had asthma since the age of 9 . She developed an asthmatic attack which failed to respond to adrenaline, and was admitted the same day. On admission she was drowsy and cyanosed with a temperature of $99^{\circ} \mathrm{F}$. $\left(37.2^{\circ} \mathrm{C}\right.$.) and respiration rate of 40 per min., with difficult and prolonged expiration; the lungs were resonant throughout with numerous rales and rhonchi; the pulse was feeble (150 per minute); blood pressure was $120 / 65 \mathrm{~mm}$. $\mathrm{Hg}$. In spite of adrenaline and intravenous aminophylline she became progressively worse and died next day. At necropsy the walls of the bronchi were infiltrated with eosinophils and the muscle layer hypertrophied, and they were filled with mucus containing eosinophils. There was moderate atheroma of the aorta and coronary arteries. Other findings were within normal limits.

Case 7: Fatal Uncomplicated Asthma (from the records of Llandough Hospital). - This 55-year-old man had a history of asthma for one year. A sudden severe attack began on the day of admission. On examination he was very cyanosed, semi-comatose, and pulseless with cold extremities. Expiration was very difficult with a generalized wheeze. Temperature was $99^{\circ} \mathrm{F}$. $\left(37.2^{\circ} \mathrm{C}\right.$.), heart rate 130 per min.; blood pressure 130/70. He was treated with $1 \mathrm{~g}$. aminophylline intravenously (which produced some improvement) three-hourly penicillin, and continuous oxygen. He died next day. At necropsy the lungs showed slight emphysema; the medium-sized bronchi were thickened and contained very tenacious mucous plugs. Microscopically the bronchi and bronchioles contained mucous plugs with polymorphs, eosinophils, and macrophages, but relatively few pus cells. Some bronchi were distended. The bronchial walls were infiltrated by polymorphs and many eosinophils, the basement membrane thickened and hyaline, and the mucous glands active. Other organs were normal.

Case 8: Asthma the Chief Cause of Death (from the records of the Hospital for Sick Children, London). -This 2-year-old girl had had asthmatic attacks for five months. On admission she was in an acute asthmatic attack, semi-comatose with difficult, rapid, grunting respirations. The face, neck, chest, and arms were emphysematous, and air in the subcutaneous tissues obscured the lung fields in a radiograph. She died a few hours after admission. At necropsy the chest, shoulders, and proximal parts of both arms were thickened and the whole face blown up; these parts felt crepitant. In the thorax the connective tissue in the anterior mediastinum was permeated with air from heart to neck; there were subpleural emphysematous bullae in the left upper lobe, air in the subpleural tissue around both hila; and in the lung there were areas of over-inflation and of collapse. Microscopically many bronchi and bronchioles contained purulent exudate, areas of emphysema alternated with areas in which alveoli were lined with eosinophilic material and filled with pale-staining, oedematous fluid. The brain was congested and other organs were normal.

Case 9: Asthma the Chief Cause of Death (from the records of the Westminster Hospital). - This 52year-old man had had asthma for five years and was admitted to hospital in a very severe attack which had started that day. He was cyanosed, in acute respiratory distress, with very poor chest expansion, and generalized expiratory rhonchi. His blood pressure was $124 / 70 \mathrm{~mm}$. $\mathrm{Hg}$; the cardiovascular system was normal. Oxygen and adrenaline produced no relief and he died early next morning. At necropsy the right lung was found to be collapsed by a pneumothorax except at the apex where there were two fibrous adhesions, and the left lung was distended by emphysema. A small tear near one of the adhesions was thought to have been the cause of the pneumothorax. In the heart there was right ventricular hypertrophy. Other organs were normal.

Case 10: Asthma the Chief Cause of Death (from the records of Llandough Hospital). - This 50-year-old man had had asthma for 20 years. He was admitted to hospital in status asthmaticus and responded well to intravenous aminophylline. Two months later he was readmitted, cyanosed, breathless with loud expiratory rhonchi. This time he failed to respond to aminophylline or adrenaline and two days later became confused, then stuporose, and died the same day. At necropsy the lungs were voluminous and soft with tenacious mucus in the bronchi. One of the major branches of the right pulmonary artery contained a recent thrombus. Microscopically there was squamous metaplasia of the lining of many bronchi; in some there was muscular hypertrophy. Eosinophils infiltrated the epithelium and walls. The alveoli were distended, the mucous glands not prominent.

Case 11: Asthma the Chief Cause of Death (personally observed at the Westminster Hospital).-This 47-year-old man had been well until seven years before admission when he developed bronchopneumonia accompanied by bronchospasm. Four similar episodes occurred between the first illness and his first hospital admission. He was then found to have the physical signs of emphysema with bronchospasm; blood pressure was $130 / 80$; temperature $102^{\circ} \mathrm{F}$., and respirations 40 per min.; radiologically patchy consolidation of both lower lobes. A few days after admission he developed signs of congestive heart failure with an enlarged and tender liver and moderate oedema of the 
lower limbs. An E.C.G. showed right axis deviation and tall $P$ waves in leads II and III. The pneumonia responded slowly to sulphadimidine and the heart failure slowly subsided with digitalis and mersalyl. After two months he was fit for discharge and the E.C.G. had become normal. The following year he had a similar attack with congestive heart failure and pulmonary infection, and six months later an attack of the same type but much less severe and with no E.C.G. changes. Later that year-nine years after his first illness-he began to have asthmatic attacks relieved by adrenaline and partially prevented by sublingual isoprenaline; an E.C.G. at this time was normal. For six weeks his attacks became more frequent and failed to respond to isoprenaline; he was admitted to hospital, cyanosed with loud expiratory rhonchi but without signs of lung consolidation or of heart failure. Adrenaline and intravenous theophylline with ethylene diamine produced some relief; treatment was continued with continuous oxygen and four-hourly ephedrine. Early next morning he became more dyspnoeic and semi-comatose, did not improve with an atropine injection, and died at 8 a.m. During this admission he was apyrexial; respirations 35 per min. and pulse rate rising to 115 per min. shortly before death. At necropsy the right lung was grossly emphysematous with bullae along the free margin; the left felt somewhat collapsed and there was adherent pleura. Microscopically there was gross emphysema with very early bronchopneumonic changes, no thickening of the muscle layer or basement membrane of the bronchioles, and the predominant cells were polymorphs with very few eosinophils. The heart was normal. The liver was congested. Other organs were normal.

Case 12: Asthma the Chief Cause of Death (from the records of Graylingwell Hospital).-This 53-yearold woman was a paranoid schizophrenic who had had asthma for 17 years. When her asthma was bad her mental symptoms improved, and, conversely, in schizophrenic exacerbations she was free of asthma. While in a mental hospital she developed a severe asthmatic attack, with great difficulty in expiration, cyanosed extremities but no fever or evidence of pulmonary infection or heart failure. Intermittent oxygen, and ephedrine and aminophylline orally, produced temporarily some relief; she then improved considerably with continuous oxygen and adrenaline but became worse again and died two days after the onset of the attack. At necropsy the significant findings were emphysema and bronchopneumonia; no histological studies were done.

Case 13: Asthma the Chief Cause of Death (personally observed at the Westminster Hospital). - This 62-year-old man had had two or three attacks of nocturnal dyspnoea a week, better in summer, since an attack of bronchitis four years previously. He had had hay fever as a child and had a sister with asthma. Ephedrine afforded relief. He attended the out-patient department, as for a month the attacks had lasted several hours every night. On examination he had a loud expiratory wheeze, basal rales, and gross emphysema; blood pressure was $150 / 100 \mathrm{~mm}$. $\mathrm{Hg}$. The liver was tender 2 in. below the costal margin. There was slight oedema of the ankles, but pulse and heart sounds were normal. Next day he went to sleep after lunch, and on waking asked the time. He had an appointment at the hospital for 2 p.m., and on being told that it was 3.30 p.m. fell back dead. At necropsy, the larynx was slightly oedematous. The bronchi and trachea were inflamed and filled with glairy, green mucopus. Both lungs were ballooned by emphysema and microscopically showed chronic emphysema with some interstitial fibrosis and collections of chronic inflammatory cells near the bronchioles. Some small bronchi were occluded by muco-cellular exudate, but there was no sign of bronchial muscular hypertrophy or eosinophilia. The heart showed generalized hypertrophy only. There was gross atheroma of the aorta; and the coronary vessels, though atheromatous, were patent throughout. The liver was enlarged and showed a mottling of the early " nutmeg" type. The spleen was congested and the adrenals had a curious mottled appearance on section. Microscopically the liver and adrenal changes were seen to be due more to fatty change than to congestion.

Case 14: Asthma the Chief Cause of Death (personally observed at the Willesden General Hospital).This 65-year-old woman had had asthma between the ages of 5 and 15 years and had then been free of it until three years previously. For 10 years she had had winter bronchitis. Her asthmatic attacks had responded to adrenaline until a few weeks before admission, and she was admitted in one which had failed to respond to several injections. On examination she was thin, dyspnoeic, and cyanosed. The chest was fixed in expiration with accessory muscles working, loud expiratory stridor and rhonchi in all areas. Blood pressure was $210 / 110 \mathrm{~mm}$. $\mathrm{Hg}$. There was no evidence of heart failure. She did not respond to adrenaline and three hours after admission suddenly collapsed with a weak pulse, inaudible heart sounds, deep cyanosis, and profuse sweating, and died five minutes later. At necropsy both lungs were found to be very emphysematous and the bronchi almost completely blocked by very tenacious mucopus adherent to the bronchial wall. Microscopically many bronchioles showed round-cell infiltration, mucous plugs containing macrophages, desquamated bronchial epithelium and eosinophils blocked many smaller bronchi, the walls of which were infiltrated by eosinophils, and eosinophils were seen in smaller numbers between the muscle layers. The right side of the heart was dilated and slightly hypertrophied and there was left ventricular enlargement. The aortic valves were distorted and incompetent due to old rheumatic carditis, and the mitral valve was slightly thickened. The coronary arteries showed early atheromatous changes. The abdominal viscera were normal apart from moderate eosinophilia of the spleen. A meningioma the size of an acorn was found hanging from the left side of the front of the falx. 
Case 15: Asthma the Chief Cause of Death (from the records of the Hospital for Sick Children).-This 21-year-old girl had had asthma since the age of 18 months. She was admitted in an attack which had started 24 hours previouisly. She was dyspnoeic and cyanosed, with signs of severe bronchospasm but none of consolidation. In spite of adrenaline she died 16 hours later. At necropsy the lungs were pale and distended; there were two areas of collapse - of half the right middle lobe and the anterior parts of the left upper lobe, but no evidence of consolidation. The trachea was congested; the bronchi and bronchioles were plugged with thick, tenacious mucopus and their mucosae were congested. The heart and other organs were normal. Microscopically there were many eosinophils in the mucous plugs and bronchial walls, and there was thickening of the muscle layer of the bronchi.

I have to thank Dr. C. J. Gavey for suggesting this investigation, and for his very helpful criticism; Dr. D. A. Williams for his kind help; and the medical staffs of the Westminster Hospital, the Hospital for Sick Children, Great Ormond Street, London, Llandough Hospital, Cardiff, the Royal Infirmary Cardiff, Graylingwell Hospital, Chichester, and the Willesden General Hospital for allowing access to case records.

\section{REFERENCES}

Alexander, H. L., Luten, D., and Kountz, W. B. (1927). J. Amer. med. Ass., 88, 882.

Antoniazzi, E.'(1933). Policlinico, Sez. med., 40, 345.

Benson, R. L., and Perlman, F. (1948). J. Allergy, 19, 129.

Bergstrand, H. (1946). J. Path. Bact., 88, 399.

Blanton, W. B., and Sutphin, A. K. (1949). Amer. J. med. Sci., 217, 169.

Brulé, M., Hillemand, P., Delarue, J., and Netter, A. (1935). Bull. Soc. méd. Hop. Paris., p. 981 .

Loc. Ibid , 59, 40.

Bubert, H. M., and Warner, C. Gardner (1935). J. Amer. med. Ass. $104,1469$.

Chafee, F. H., Ross, J. R., and Gunn, E. M. (1942). Ann. intern. Med., 17, 45

Clarke, J. A. (1930). Arch. intern. med., 45, 624.

Coke, F., and Coke, H. (1939). Asthma, p. 237. Wright, Bristol. Colton, W. A., and Ziskin, T. (1936). Med. Bull. Veteran' Adm., 13, 117

Craige, B. (1941). Arch. intern. Med., 67, 399.
Cummings, G. O. (1946). Ann. Otol., St. Louis, 85, 136.

Dehner, W. (1927). Klin. Wschr., e, 1412

Facquet, J., and Claisse, R. (1939). Paris med., 2, 113.

Fowler, K. (1937). Penn. med. J., 40, 720

Gay, L. N. (1946). The Diagnosis and Treatment of Bronchial Asthma. Baillière, Tindall and Cox, London.

Hamburger, J., Milliez, P., and Halpern, B. (1947). Bull. Soc. méd. Hôp. Paris, 63, 432.

Hansen, O. S. (1936). Minn. Med., 19, 445.

Harkavy, J. (1930). J. Allergy, 1, 136.

- (1941). Arch. intern. Med., 67, 709

Huber, H. L., and Koessler, K. K. (1922). Ibid., 30, 689.

Kayssi, A. I.'(1948). Brit. med. J., $2,131$.

Kountz, W. B., and Alexander, H. L. (1928). Arch. Path. Lab. Med. 5,1003

Lamson, R. W., and Butt, E. M. (1937). J. Amer. med. Ass., 108, 1843 .

Lemierre, A., Léon-Kindberg, M., and Lévesque, J. (1923). Presse méd., 31, 613.

Lennox, B. (1948). J. Path. Bact., 60, 620.

Macdonald, I. G. (1933). Ann. intern. Med., 6, 253.

Magee, A. V. (1949). Practitioner, 163, 134

Massachusetts General Hospital Reports (1946). Case record No. 32192 . New Engl. J. Med., 234, 639.

Meakins, J. C. (1944). The Practice of Medicine, 4th edit. Kimpton, London.

Michael, P. P., and Rowe, A. H. (1935). J. Allergy, 6, 150

Mitchell, H. S., and Bacal, H. L. (1950). Canad. med. Ass. J., 63, 467.

Moulis, A. (1950). J. franc. med. Chir. thorac., 4, 273.

Old, H. (1933). J. Allergy, 4, 122.

Peterson, H. (1947). Ibid., 18, 413 .

Rackemann, F. M. (1926). Boston med. surg. J., 184, 531

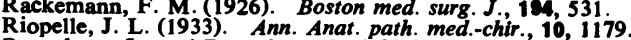

Rosenberg, J., and Rosenberg, L. (1938). Amer. J. med. Sct., 105, 682.

Schwartz, B. M., McIlroy, G. H., and Warren, H. A. (1945). Air Surgeon's Bull., 2, 146.

Schwartz, M. (1949). Lancet, 1, 1001.

Serafini, U. (1950). Policlinico, Sez. prat., 57, 33

Steinberg, B., and Figley, K. D. (1928). J. Lab. clin. Med., 13, 921

Thieme, E. T., and Sheldon, J. M. (1938). J. Allergy, 8, 246.

Thieme, E. T., and Sheldon, J. M. (1938). J. A.

Thomson, J. G. (1945). J Path. Bact., 57, 213. Wash., 3, 50 .

Traisman, A. S. (1941). Arch. Pediat., 85, 407.

Trowbridge, M. (1944). Arch. intern. Med, 73, 460.

Unger, L. (1945). Sth med. J., Bgham, Ala., 38, 513.

Vance, B. M., and Strassmann, G. (1942). Arch. Path., Chicago, 34,

Vaughan, W. T. (1948). Practice of Allerg.v, 2nd edit. Kimpton, London.

Villanova, P. (1948). Presse méd., 56, 828.

Waldbott, G. L. (1935). Amer. J. Dis. Child., 49, 1531.

Walton, C. H. A., Penner, D. W., and Wilt, J. C. (1951). Canad. med. Ass. J., 64,95 .

Williams, E. O., and Williams, G. E. O. (1949). Brit med J 2, 897

Wilmer, H. B., Eiman, J., and Miller, M. M. (1936). J. Allergy, 7,

Wilson, K. S., and Alexander, H. L. (1947). J. Mo. med. Ass., 44, 664

Wright, C. B. (1930). J. Amer. med. Ass., 44, 1218. 